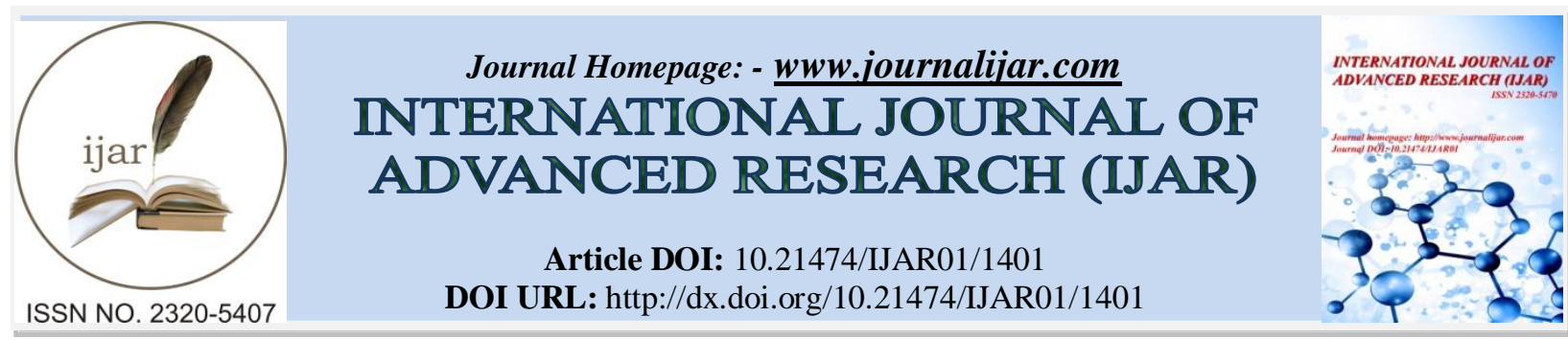

RESEARCH ARTICLE

\title{
A CRITICAL EVALUATION OF RTE ACT IN RELATION TO ITS IMPACT ON TEACHER TEACHING IN SCHOOLS.
}

Dr. Pawan Kumar Kamra' and "Uma Sheokand"

1. Department of Pblic Administration USOL, Panjab University, Chandigarh (India)-160014.

2. Research Fellow, Panjab University, Chandigarh (India)-160014.

\section{Manuscript Info}

Manuscript History

Received: 18 June 2016

Final Accepted: 13 July 2016

Published: August 2016

Key words:-

Right to Education, School Administration, Primary Teachers, Job satisfaction, Condition of teachers.

\section{Abstract}

In the era of globalization, teachers are the most cardinal actors in the entire educational endeavour. Academic excellence of schools is largely indicative of the performance level of the respective teaching faculty. RTE act is provision which provide free and compulsory primary education of equitable quality, based on principles of equity and non-discrimination to all children in India. This act also laid down various norms which are closely related to job satisfaction of teachers, for instance norms regarding teacher pupil ratio, classroom teacher ratio, negation of corporal punishment, work load on teachers etc.

An analytical approach undertaking various aspects related to RTE act, is necessary to understand and to resolve the issues of teachers particularly related to teachers. Job satisfaction is a comprehensive reaction towards various factors. In order to attain educational goals, there is also a dire need to ascertain the job satisfaction of teachers. Hence, this research study attempted to study the teachers' satisfaction regarding various provisions of RTE Act. This study also endeavored to make a comparative analysis between government and private school teachers in relation to their satisfaction towards various provisions of RTE act.

Lack of infrastructure, teaching learning equipments and other facilities, disproportion of pupil teacher ratios and classroom teachers ration, problems faced due to negation of punishment and negation of private tuition norms gives rise to teachers' dissatisfaction.

Better infrastructure, availability of proper teaching equipments, proper implementation of pupil teachers' norms and classroom teachers' norms, additional staff for implementation of mid day meal program in school can open the gate way to more efficient people to adopt teaching profession and to achieve long cherished educational goals in India. 


\section{Introduction:-}

Education is a fundamental human right. It is essential for the exercise of all other human rights and to live a quality life. To provide free and compulsory education to all children is a goal that is enshrined in the Indian Constitution as a Fundamental Right. This, indeed, is also the focus of the World Declaration on 'Education for All', adopted nearly 25 years ago, in Jomtien. The World Education Forum, held in Dakar (2000), reiterated the commitment of the global community and approved a comprehensive set of goals in the areas of early childhood care in education, primary education and quality of education. Following this commitment, India prepared a National Plan of Education (2002) delineating various programmes and strategies for achieving various Education for All (EFA) Goals; which was further strengthened with enactment of Right of Children to Free and Compulsory Education (RTE) Act, 2010. The RTE Act provides legal status to free and compulsory education to all children in the age group of six to fourteen years, beside making it a fundamental right under article $21 \mathrm{~A}$, inserted in the constitution (i.e. $86^{\text {th }}$ Amendment, 2002). This act defines various standards, free entitlements and provides a justifiable legal framework that entitles all children between the ages of 6-14 years free and compulsory admission, attendance and completion of elementary education ${ }^{1}$. This act provide for rights based approach. Under it, there is provision for free of cost compulsory education of equitable quality, based on principles of equity and non-discrimination to all children in India. It also aimed to remove the educational disparities and to improve the infrastructural facilities. It provides for availability of equipment and support services which will have significant impact on access, enrollment, and retention rate with quality education in India ${ }^{2}$. Right to Education ${ }^{3}$ also laid down the norms for teacher pupil ratio, classroom teacher ratio i.e. Proper proportion of teachers and pupil in school and it also emphasized on buildings and infrastructure, school-working days, teacher-working hours, which are the indicators for the checking quality of education besides effectiveness of teaching in schools

\section{RTE Act and Teacher's Satisfaction:-}

No doubt RTE Act provided standardized norms for elementary education but it also put many obligations on teachers which are as follows:

\section{Provisions related to teachers under RTE Act:-}

1. Academic responsibilities of teachers and other issues related to teaching learning processes are also specified by this act.

2. It made provisions for development of school curriculum.

3. It fixed the school working hours of the teachers.

4. It also provides for prohibition of deployment of teachers for non-educational work, other than decennial census, elections to local authority, state legislatures and parliament, and disaster relief.

5. It specifies the norm regarding Classroom Teacher Ratio in schools.

6. RTE standardized the Pupil Teacher Ratio norms.

7. As RTE Act negates the physical punishment and mental harassment, It made a provision for 6 month imprisonment to teacher if pupil is abused, punished physically or harassed mentally

8. Negates private tuition by teachers

\section{Objective:-}

The objective of the subject matter is to make comparative analysis of job satisfaction of government and private primary school teachers in relation to RTE act. This study also aims to study various provisions under RTE act, which are related to job satisfaction of teachers which are as follows:

1. INFRASTRUCTURE IN SCHOOL

2. PUPIL TEACHER RATION IN SCHOOLS

3. PROVISION OF 'NEGATION OF CORPORAL PUNISHMENT'

\section{Methodology:-}

The study would employ the following research methodology

\footnotetext{
${ }^{1}$ Right to Free and Compulsory education Act, (2010) New Delhi; MHRD, Government of India, pp.12-26

${ }^{2}$ Ib.id.

${ }^{3}$ http://mhrd.gov.in/rte Accessed 30th may 2014.
} 


\section{Sample Selection:-}

The various administrative Blocks of Kaithal District as per the Statistical and Economic Survey of Haryana can be ranked on different literacy levels. The same may be perused from table 1.

Table 1:-

\begin{tabular}{|l|l|l|}
\hline \multicolumn{2}{|l|}{ Literacy Level of the Blocks in Kaithal District } \\
\hline & Blocks & Literacy Percentages \\
\hline $\mathbf{1}$ & Kaithal & $\mathbf{6 6}$ \\
\hline $\mathbf{2}$ & Pundri & $\mathbf{7 0}$ \\
\hline 3 & Rajond & 66 \\
\hline $\mathbf{4}$ & Kalayat & $\mathbf{6 4}$ \\
\hline 5 & Guhla & 65 \\
\hline 6 & Sivan & 67 \\
\hline
\end{tabular}

Source: Statistical and Economic Survey of Haryana, 2011-12

Three Blocks viz. Pundri, Kaithal, and Kalayat representing highest, middle, and lowest in the literacy level have been selected as strata of sample (Statistical and Economic Survey of Haryana, 2011-12).

\section{Sample:-}

A total sample of 300 teachers was selected by employing random sampling technique. Thus the sample comprised of 180 government and 120 private schools teachers of the sampled area.(" Government Schools are almost double the number of Private Schools) Thus the sample comprised of 40 government and 33 private schools of the sampled area. An effort has been made to divide the sample into sub stratas like age, gender, status of job, academic qualification, marital status, and income.

The number of female teachers outnumbered the male teachers so equal representation to gender is the limitation of this part of the study. Sample included both permanent and contractual teachers.

\section{Use of Person's Chi Square and P. Value}

The data collected through structured and unstructured research questionnaire was processed and analyzed. In the effort of processing the data, besides using percentages, the researcher had used Person's Chi square test result and p- value. The following parameters have been employed to analyze the data.

\begin{tabular}{|l|l|}
\hline Chi Square Test \\
\hline Assumptions of Chi square test result in the present study \\
\hline 0.00 to 0.01 & Highly Significant \\
\hline Above 0.02 up to 0.05 & Significant \\
\hline
\end{tabular}

The assumptions considered while analyzing the primary data given in the Tables

Only the attributes having significant or highly significant relations with the different variables (i.e. questions) had been explained further. An attempt had been made to elucidate the statistical data quantitatively, as well as qualitatively in relation to the on interview, discussions and observations done by the researcher.

\section{COMPARATIVE ANALYSIS OF SATISFACTION OF GOVERNMENT AND PRIVATE PRIMARY SCHOOL TEACHERS TOWARDS RTE ACT}

Teacher's Satisfaction Regarding Infrastructure In School:-

Every individual prefers good, secure and comfortable work environment and surroundings. Good working conditions include work place conditions i.e. lightning room temperature, ventilation, cleanliness etc. It also impact on job satisfaction of employee. ${ }^{4}$ The RTE Act made provisions for all weather building schools having at least one classroom for every teacher and an office-cum-store-cum-Head teacher's room, as well as barrier- free access, separate toilets for boys and girls, safe and adequate drinking water facility for all children under Right to education act, $2009^{5}$. Moreover, under section 19 and 25 of RTE, 2009, no recognition shall be granted to a school unless it fulfils norm and standards specified by the act.

\footnotetext{
${ }^{4}$ M.S.Weidemann Brill, and BOSTI Associates, (2001) "Disproving widespread myths about workplace design" Jasper; Kimball Internationa IN, Vol. 28 (8), p 38.

${ }^{5}$ Right to Education Act, 2009: Norms and Standards for School (Section 19 and 25)
} 
Building, Classrooms, Staffroom, Furniture (Chair, Table etc):-

This study also attempted to analyze the perception of teachers towards school infrastructure. The table 2 revealed that $83.3 \%$ government teachers give affirmative assurance by saying that they were satisfied with the infrastructure facilities in the school. However, astoundingly $97.5 \%$ private school expressed contentment towards school infrastructure. During discussions with respondents too, it come out that the condition of most of private schools was more commensurate, decent and sufficing as compared to government schools. In addition to this teachers were more satisfied with the infrastructure facilities in private schools. The researcher also observed that the private schools teachers had sophisticated, well furnished buildings and better infrastructure facilities as compared to government schools. Even the classrooms in private schools were also splendidly equipped. The Chi square results $\left(\mathrm{X}^{2}=14.760, \mathrm{p}<0.00\right)$ was also found highly significant as there was variation in the proportion of responses among the government and private school respondents covered under study.

Table 2:- Are you satiated with Infrastructure facilities (Building, Classrooms, Staffroom, Furniture (Chair, Table) in the school? Yes/ No/ No Comments

\begin{tabular}{|c|c|c|c|c|c|c|}
\hline \multirow{2}{*}{ Type of school } & & & & & \multirow{2}{*}{ Chi-square } & \multirow{2}{*}{ p-value } \\
\hline & Yes & No & No Comments & Total & & \\
\hline \multirow{2}{*}{ Govt. School } & 150 & 30 & 0 & 180 & \multirow{4}{*}{14.760} & \multirow{4}{*}{$.000 * *$} \\
\hline & $83.3 \%$ & $16.7 \%$ & $0.0 \%$ & $100.0 \%$ & & \\
\hline \multirow{2}{*}{ Pvt. School } & 117 & 3 & 0 & 120 & & \\
\hline & $97.5 \%$ & $2.5 \%$ & $0.0 \%$ & $100.0 \%$ & & \\
\hline \multirow{2}{*}{ Total } & 267 & 33 & 0 & 300 & & \\
\hline & $89.0 \%$ & $11.0 \%$ & $0.0 \%$ & $100.0 \%$ & & \\
\hline
\end{tabular}

Source: Computed from Primary data $\mathrm{p}$ - value $<0.01$ is highly significant denote $* *$

Hence, it was inferred that private schools teachers as compared to government school teachers were more satisfied with the infrastructure facilities (Building, Classrooms, Staffroom, Furniture (Chair, Table) in schools.

Basic Facilities (like Drinking Water, Toilets and First Aid) in School

The central and state governments' endeavored to provide basic infrastructure in school. The table 3 reveales that 97.5\% private school teachers consented that there were basic facilities (like drinking water, toilets and first aid facilities) available in school. Whereas, only $82.2 \%$ government school teachers confirmed the availability of fundamental facilities in school. During discussion, private school respondents openly favored that there was apt, commensurate, and compatible basic facilities in their schools. It was laid to open by government school respondents that the conditions of basic facilities in government schools were not satisfactory. Although, drinking water facilities, toilets and first aid facilities were available in most of the schools; but the condition of toilets in government school was atrocious, awful, and sad. Even the Chi square results $\left(X^{2}=22.736, p<0.00\right)$ was found highly significant as there was variation in the proportion of responses among the government and private school respondents covered under study.

Table 3:- Are there adequate basic facilities (like drinking water, toilets and first aid facilities) in school? Yes/ No/ No Comments

\begin{tabular}{|c|c|c|c|c|c|c|}
\hline \multirow{2}{*}{ Type of school } & & & & & \multirow{2}{*}{ Chi-square } & \multirow[t]{2}{*}{ p-value } \\
\hline & Yes & No & No Comments & Total & & \\
\hline \multirow{2}{*}{ Govt. School } & 148 & 30 & 2 & 180 & \multirow{4}{*}{22.736} & \multirow{4}{*}{$.000 * *$} \\
\hline & $82.2 \%$ & $16.7 \%$ & $1.1 \%$ & $100.0 \%$ & & \\
\hline \multirow{2}{*}{ Pvt. School } & 117 & 0 & 3 & 120 & & \\
\hline & $97.5 \%$ & $0.0 \%$ & $2.5 \%$ & $100.0 \%$ & & \\
\hline \multirow{2}{*}{ Total } & 265 & 30 & 5 & 300 & & \\
\hline & $88.3 \%$ & $10.0 \%$ & $1.7 \%$ & $100.0 \%$ & & \\
\hline
\end{tabular}

Source: Computed from Primary data p-value $<0.01$ is highly significant denote $* *$

Thus, it was inferred that private schools as compared to government school had more adequate basic facilities (like Drinking Water, Toilets and First Aid) in school. 
Satisfaction of Teachers Regarding Pupil Teachers Norms In Schools:-

RTE act standardized the Pupil Teacher ratio, it is considered one of the main indicators in the primary education growth. RTE act has fixed the upper limit of pupil per teacher in a primary class; which is as shown in Figure 2.

Figure 2:- Standardized Norm Teacher Pupil under RTE

\begin{tabular}{|c|c|c|c|c|c|}
\hline \multicolumn{6}{|c|}{ Teacher Pupil Norms Under Right to Education Act, 2009} \\
\hline \multicolumn{7}{|c|}{ From 1st to 5th Class (Pupil and Teacher Ratio) } \\
\hline $\begin{array}{c}\text { Pupil=2 } \\
\text { Teachers }\end{array}$ & $\begin{array}{c}\text { Pupil = 3 to 90 } \\
\text { Teachers }\end{array}$ & $\begin{array}{c}\text { 91 to 120 } \\
\text { Pupil = 4 } \\
\text { Teachers }\end{array}$ & $\begin{array}{c}121 \text { to 200 } \\
\text { Pupil = 5 } \\
\text { Teachers }\end{array}$ & $\begin{array}{c}>150 \\
\text { Pupil =5 } \\
+1 \text { Head } \\
\text { Teacher }\end{array}$ & $\begin{array}{c}>200= \\
\text { PTR Shall } \\
\text { not exceed } \\
\text { 40Pupil }\end{array}$ \\
\hline
\end{tabular}

Teacher's satisfaction regarding Pupil Teacher Ratio maintained in School:-

Since, it is more convenient to handle small classes. The table 4 showed that $73.9 \%$ government school teachers consent that they were satisfied with the Pupil Teacher Ratio (PTR) maintained in school, while $89.2 \%$ private school teachers were contented with PTR followed in their school. During research it was observed that in most of the private schools there was mostly less than 40 pupils in each primary class. However, it was also found during observation by researcher that the PTR norms in government schools; either outnumbered or less than the prescribed standards of RTE act. Even, the Chi square results $\left(X^{2}=11,859, \mathrm{p}<0.01\right)$ was found highly significant as there was variation in the proportion of responses among the government and private school respondents covered under study. Therefore, it was concluded that the private as compare to government school teachers were more satisfied with the Pupil Teacher Ratio maintained in school. As there was less number of pupils in private schools in each class.

Table 4:- Are you satisfied with the Pupil Teacher Ratio maintained in your school? Yes/ No/ No Comments

\begin{tabular}{|c|c|c|c|c|c|c|}
\hline \multirow{2}{*}{ Type of school } & & \multirow{2}{*}{ Chi-square } & \multirow[b]{2}{*}{ p-value } \\
\hline & Yes & No & No Comments & Total & & \\
\hline \multirow{2}{*}{ Govt. School } & 133 & 39 & 8 & 180 & \multirow{4}{*}{11.859} & \multirow{4}{*}{$.008 * *$} \\
\hline & $73.9 \%$ & $21.7 \%$ & $4.5 \%$ & $100.0 \%$ & & \\
\hline \multirow{2}{*}{ Pvt. School } & 107 & 9 & 4 & 120 & & \\
\hline & $89.2 \%$ & $7.5 \%$ & $3.3 \%$ & $100.0 \%$ & & \\
\hline \multirow{2}{*}{ Total } & 240 & 48 & 12 & 300 & & \\
\hline & $80.0 \%$ & $16.0 \%$ & $4.0 \%$ & $100.0 \%$ & & \\
\hline
\end{tabular}

Source: Computed from Primary data p-value $<0.01$ is highly significant denote **

\section{$\underline{\text { Teachers' Satisfaction regarding Provision of 'Negation Of Corporal Punishment' }}$}

Teacher's Perception Regarding Student's Behavior:-

Sometime pupil's behavior is troublesome and irritating, which cause stress and create difficulty for teachers to handle them. The table 5 revealed that $63.3 \%$ government school teachers accepted that student's behavior was not at all troublesome and irritating in the class, as compared to $77.5 \%$ of private school teachers who acknowledged that students' behavior was not at all troublesome in class. During conversations with respondents, private school teachers admitted more as compared to government school teachers that student's behavior in the class was manageable and agreeable. Even though the Chi square results $\left(\mathrm{X}^{2}=12.636, \mathrm{p}<0.02\right)$ was found significant as there was variation in the proportion of responses among the government and private school respondents covered under study. Therefore, it was inferred that although primary pupil were difficult to handle still, private school teachers as compared to government school teachers revealed more that student's behavior was not at all troublesome in the class. 
Table 5:- Does the student's behavior troublesome in the class? Yes/ No/ No Comments

\begin{tabular}{|c|c|c|c|c|c|c|}
\hline \multirow{2}{*}{ Type of school } & & & & & \multirow{2}{*}{ Chi-square } & \multirow{2}{*}{ p-value } \\
\hline & Yes & No & No Comments & Total & & \\
\hline \multirow{2}{*}{ Govt. School } & 63 & 114 & 3 & 180 & \multirow{4}{*}{12.636} & \multirow{4}{*}{$.002 *$} \\
\hline & $35.0 \%$ & $63.3 \%$ & $1.7 \%$ & $100.0 \%$ & & \\
\hline \multirow{2}{*}{ Pvt. School } & 21 & 93 & 6 & 120 & & \\
\hline & $17.5 \%$ & $77.5 \%$ & $5.0 \%$ & $100.0 \%$ & & \\
\hline \multirow{2}{*}{ Total } & 84 & 207 & 9 & 300 & & \\
\hline & $28.0 \%$ & $69.0 \%$ & $3.0 \%$ & $100.0 \%$ & & \\
\hline
\end{tabular}

Source: Computed from Primary data p-value $<0.05$ is highly significant denote *

\section{Teachers' Perception Regarding Provision of 'Negation of Corporal Punishment':-}

It was the only aspect where most teachers thought corporal punishment was effective for maintaining discipline, but impact negatively on teacher student relations, as well as impact badly on students' mental ability and creativity. ${ }^{6}$ In table 6 it was revealed that, 50.6\% government school teachers desired that provision of "negation of corporal punishment should be eradicated from the RTE act, whereas $60.8 \%$ private school teachers desired that this provision should not be removed from the RTE act. During dialogue with teachers it was found that most of the teachers irrespective of their type of school they belonged to were aware about the provision of imprisonment of teacher, if pupil were abused, punished and harassed physically or mentally by teacher. Even though it was also established that most of the school teachers were not aware about the exact time period for the punishment prescribed under RTE act, but they were fearful about RTE act's provisions of 'negation of corporal punishment'. During informal dialogues with respondents it was discovered that government school teachers as compare to private school teachers strengthen the point more that provision of "negation of corporal punishment should be amputated (cut off) from the RTE act. Even though the Chi square results $\left(\mathrm{X}^{2}=8.595\right.$, $\left.\mathrm{p}<0.014\right)$ was found significant as there was variation in the proportion of responses among the government and private school respondents covered under study. Therefore it can be elucidated that the government school teachers desired more that provision of 'negation of corporal punishment should be removed from the RTE act.

Table 6:- Do you feel that provision of 'negation of corporal punishment should be removed from the RTE act? Yes/ No/No Comments

\begin{tabular}{|l|l|l|l|l|l|l|}
\hline \multirow{2}{*}{ Type of school } & \multicolumn{5}{|c|}{ Chi-square } & \multirow{2}{*}{ p-value } \\
\cline { 2 - 7 } & Yes & No & No Comments & Total & & \\
\hline \multirow{2}{*}{ Govt. School } & 91 & 85 & 4 & 180 & \\
& $\mathbf{5 0 . 6 \%}$ & $\mathbf{4 7 . 2 \%}$ & $\mathbf{2 . 2 \%}$ & $\mathbf{1 0 0 . 0 \%}$ & \multirow{3}{*}{8.595} & \multirow{2}{*}{.14* } \\
\hline \multirow{2}{*}{ Pvt. School } & 41 & 73 & 6 & 120 & & \\
\cline { 2 - 7 } & $\mathbf{3 4 . 2 \%}$ & $\mathbf{6 0 . 8 \%}$ & $\mathbf{5 . 0 \%}$ & $\mathbf{1 0 0 . 0 \%}$ & & \\
\cline { 2 - 7 } & 132 & 158 & 10 & 300 & & \\
\hline
\end{tabular}

Source: Computed from Primary data p-value <0.05 is significant denote*

\section{Main Findings Of The Study:-}

These following are the main findings of this study:

1. Private schools teachers were more satisfied with the infrastructure facilities (Building, Classrooms, Staffroom, Furniture (Chair, Table) in schools as compared to government school teachers.

2. Private schools had more adequate basic facilities (like Drinking Water, Toilets and First Aid) in school as compared to government school.

3. Private were more satisfied with the Pupil Teacher Ratio maintained in school as compare to government school teachers.

4. Private school teachers revealed more that student's behavior was not at all troublesome in the class as compared to government school teachers.

5. Government school teachers desired more than private school teachers hat provision of "negation of corporal punishment should be removed from the RTE act.

\footnotetext{
${ }^{6}$ (Nughat, Janjua, \& Masood, 2012)
} 


\section{Conclusion:-}

It is the responsibility of government, educational administrator and policy makers to invest time, efforts and make measures to enhance level of job satisfaction of teachers. There are several policies formulated by governments for welfare of teachers. RTE act has been implemented to uplift primary education. No doubt this act is very successful in improving the condition of primary education, but due to ineffective and improper implementation of RTE act norms (like PTR, negation of corporal punishment, wok load etc) this act impacted negatively on teachers. There is dire need to implement the norms of RTE act in proper manner. For the achievement of primary education goals, teachers should be given special concern in policy making. There should be proper infrastructure facilities in school, and staff should be recruited on vacant posts for maintaining proper PTR in schools. In addition to this, proper implementation and regular monitoring of those policies is equally as important, as to make those policies. RTE act should be managed and implemented in such a way that besides achieving the educational goals it also satisfies the needs and aspirations of teachers working in schools. The Government and community both should endeavour to create more conducive conditions, which would help motivate and inspire teachers on constructive and creative lines. 